\title{
ROSMINI'S METAPHYSICAL EVIDENCE FOR THE EXISTENCE OF GOD
}

\begin{abstract}
Rosmini is of the opinion that the soul consists of both a bodily (natural) and a godly component. Both components unite in humankind. In Rosmini's cosmology, humankind is viewed in relation to God and the world (cosmos). Cosmology cannot be comprehensively explained without linking ontology and theology, in particular. Rosmini treats human knowledge of God's existence ontologically. According to Rosmini, we will not comprehend metaphysical or spiritual matters without understanding temporal matters (cosmology). Cosmology forms part of a higher science, namely ontology and even more so theology. Ontology treats being in its essence, in terms of which Rosmini identifies three forms, namely the ideal, the real (or actual) and the moral. The essence of being in all three forms should be similar, yet these forms differ. Although humankind is equal to the godly image, God and humankind differ in essence. Humankind shares in the ideal, the actual and the moral forms by means of the soul. Rosmini is of the opinion that the moral form, in relation to reality, forms the ideal Being. The ideal Being is infinite and essentially perfect. The infinite perfect Being can therefore not be humankind. Humankind is unable to fully comprehend the perfect Being (God). The perfect Being (God) in his totality and completeness is thus not subject to human knowledge or existence. Human reason can only know what is revealed to it through nature. According to Rosmini, we can know God in a way that surpasses human intelligence, and we can therefore not form a positive but raher a negative understanding of God.
\end{abstract}

Dr. Nico P. Swartz. Head: Unit for Legal Historical Research, Dept. Roman Law, Legal History and Comparative Law, UFS, Faculty of Law, Bloemfontein, e-mail: swartznp.rd@ufs.ac.za. The author expresses his gratitude to Prof. H.A. Wessels. 


\section{ROSMINI'S METAPHYSICAL EVIDENCE FOR THE EXISTENCE OF GOD}

Humankind is the point of departure in Rosmini's examination of God. In his works Antropologia in Servizio ${ }^{1}$ and Psicologia ${ }^{2}$ he examines the godliness of the human soul. Rosmini assumes that the human soul consists of two components: a bodily (natural) and an intellectual (godly) component. ${ }^{3}$ The intellectual (godly) component comprises the highest norm in humankind.

Rosmini is of the opinion that, although the soul consists of both a bodily (natural) and a godly (supernatural) component, these unite in humankind. ${ }^{4}$ This thought shows parallels with the Thomistic analogia entis and his doctrine of participation (Van der Vyver 1975:66).

Rosmini is also of the opinion that the soul (the supernatural godly component) provides the basis for all humankind's internal observations. Cleary (1992:23) explains that Rosmini perceived the soul as consisting of two elements, the perceptible and the sensitive; this demonstrates similarities with the Aristotelian-Thomistic doctrine of form/matter. He argues that this form (as the supernatural component) is known as "the soul," although the ideational being can, in its totality, be attributed to human intelligence (Cleary 1992:26). Rosmini thus equates the ideational being (as the godly supernatural element) with human intelligence.

\section{Davidson cites Winterton:}

[Rosmini] admits, indeed, that his ideal Being is an appurtenance of the Absolute Being and that if this being were to put forth its own activity, and so complete and terminate itself, we should see God; but he adds, "until this happens ... we can only say ... that in this life, certa, quamvis adhuc tenuissima forma cognitionis, attingimus Deum" (that although knowledge of the image is still limited today, one will certainly still arrive at God) (Winterton 1888:622).

1 Rosmini (1991a), title page. Anthropology as an aid to moral science.

2 Rosmini (1999), title page. Psychology. This work consists of four volumes in the following order: Essence of the human soul; Development of the human soul; Laws of animality, and Opinions about the human soul.

3 In this context the godly would refer (under the influence of Aristotelianism-Thomism) to the supernatural element or component of the soul.

4 Rosmini (1991a:viii-ix) explains: "The human being [...] [encompasses] animality and intelligence [...] [thus] intellect and reason on the one hand (supernatural component) and will and freedom on the other (natural component) [...]". 
John-Stevas (1955:83) asserts that Rosmini's theological viewpoints will perhaps in future form the basis of modern Thomism. Thomas Aquinas wrote during the $12^{\text {th }}$ century and his ideas will become stagnant. It has thus become Rosmini's task to continue the Thomistic tradition into the modern era: "Rosmini, perhaps the greatest of modern Italian philosophers, whose idealist philosophy may one day replace Thomism as the 'official' philosophy of the Roman Church [...]." According to Davidson (1882:616), Rosmini continued the Thomistic tradition in the $19^{\text {th }}$ century. He linked traditional (classical) Thomism with modern tendencies. However, according to Davidson, Thomism has not always been free from criticism within its own ranks and criticism from dissident thinkers about Church doctrine. In this process, Rosmini's theological viewpoints enjoyed considerable respect, placing him on an equal footing with Thomism. Theologically, Rosmini endeavoured to remain true to the fundamental value of the traditional (classical) Thomism, treating the Thomistic points of departure in such a way that they acquire a new dynamic actuality.

\section{ROSMINI'S SOCIAL PHILOSOPHY (COSMOLOGY AND ONTOLOGY)}

\subsection{His cosmological foundation for the existence of God}

Rosmini regards cosmology as forming part of metaphysics in conjunction with ontology and natural theology. In Rosmini's cosmology, humankind is viewed in relation to God and creation (cosmos). Rosmini is of the opinion that if humankind displays the same qualities as God, for example, necessity, universality, eternity, then he must always have existed. ${ }^{5}$ By contrast, if humankind displays the qualities of contingency, particularity, and temporality, then it must have had a beginning (inception). The latter is acceptable, because, cosmologically, humankind does not determine its own beginning but has an origin. According to Rosmini, cosmology cannot be comprehensively explained without linking it to ontology and theology, in particular. Rosmini is thus of the opinion that we cannot comprehend cosmology (the existence of the world) without dealing with the nature and workings of God, its author. Rosmini postulates that knowledge of God's existence is an essential human requirement. ${ }^{6}$

Rosmini also treats human knowledge of God's existence ontologically. According to Rosmini, we will not comprehend metaphysical or spiritual matters

5 This sentiment is indicative of Plato's doctrine of the pre-existence of the soul.

6 It is important to distinguish between God and humankind. They must be two separate entities. During the medieval period some Roman emperors (Augustus) wrongfully regarded themselves as gods. 
without understanding the temporal matters (cosmology). Conversely, cosmology cannot in its own right be regarded as an independent science. In Rosminian thought, Cleary (1992:53) states, cosmology can only form part of a higher science, namely ontology, and above all theology.

\subsection{Rosmini's ontological foundations for the existence of God}

According to Davidson (1882:326), Rosmini divides ontological science into two parts, namely the ontological self and natural theology. $\mathrm{He}$ is of the opinion that ontology treats a being in its essence. In terms of a being's essence, Rosmini identifies three forms, namely the ideational, the real or actual, and the moral. ${ }^{7}$ These forms serve as Rosmini's ontological foundations for the existence of God.

According to Rosmini, the essence of a being in all three forms should be similar, although they do differ. Rosmini distinguishes between the three forms in order to separate God and humankind. He remarks that God is an ideational Being, while humankind is limited. God, as ideational Being, is perfect, while humankind, as real being, is imperfect. The moral form bridges the divide between God and humankind. Humankind must unite with God. It is the task of the moral form to bring about unity between God and humankind. Rosmini explains:

[Moral] good is infinite in its nature, having always infinite being for its object. Limited being is never seen by perception as alone and as having no relation to itself, but always as united to the ideal [...] (Davidson 1882:328-9).

Although humankind is equal to the godly image, God and humankind differ in essence. This difference (as explained above) lies in the fact that humankind possesses the qualities of contingency, particularity and temporality, while God displays the qualities of necessity, universality, eternity, etc. Davidson (1882:328-9) argues that Rosmini is of the opinion that the highest forms of being are the ideational, the actual and the moral forms - namely God. Humankind partakes in the ideational, the actual and the moral forms by means of the soul. This godly quality, the soul or reason, indicates the presence of natural law among men. Natural law also possesses the qualities of universality and eternity and is therefore law inculcated in the hearts of humankind. Natural law regulates humankind's actions towards other people in society. Humankind must thus allow reason to guide its actions in such a way that it is able to imitate the exaltedness of these godly qualities. The relation between natural law and reason (supernatural godly component) is that they share the qualities of universality, eternity and necessity. Herewith, the

7 Davidson (1882:326): “ $\ldots$ [Ontology] treats of being in its essence, and in the three forms in which its essence is - the ideal form, the real form, and the moral form." 
idea of analogia entis (between God and humankind) and the imago Dei (image of God) is brought to pass by humankind's unification with God. ${ }^{8}$

Under the influence of Stoicism, the imago Dei was regarded as the spark of godliness in humankind, and under the influence of Aristotle (and consequently that of Aquinas), human reason was viewed as the sign of the image of God. ${ }^{9}$ ) According to Rosmini, a Being (God) is regarded as the object of reason and serves as the principle for the reality as expressed in ontological form (Davidson 1882:333).

Rosmini is of the opinion that the moral form, in relation to reality, forms the ideational Being (God). But humankind cannot become God, because it differs in essence. Humankind can only be exalted to moral creatures. Rosmini declares that humankind unites the moral form (thesis) with the actual form (the preservation of the law - antithesis) in order to bring about the Ideational Form (God) (synthesis). ${ }^{10}$ According to Rosmini, the ideational Being is infinite and essentially perfect. In this manner we can assume that moral goodness is infinite by nature and that God is thus the infinite Being. The infinite perfect Being can therefore not be humankind. Rosmini is of the opinion that imperfect, limited being (humankind) is not independent but is necessarily united with the ideational Being which is perfect and infinite. This, according to Rosmini, forms the actual quality of what morality is, and is what encompasses the entirety of a being. In so far as the being is moral, it has the capacity to bring the subject or humankind into harmony with its object, God. Through humankind's directedness towards God, humankind, as subject, is perfected and completed with respect to fulfilling its rights and duties in society. On the basis of natural law and positive law, humankind is thus now able to exercise moral judgement over its actions. Both the natural and positive laws are from God. As mentioned, natural law implies moral prescriptions inculcated by God into humankind's heart. Positive law (man-made law, promulgated by authority to regulate the conduct of the citizens) is also regarded as God-given law due to the principle, omnes enim potestas a Dei (all power is derived from God).

8 Davidson (1882:333). According to Rosmini, ontology determines that God cannot be comprehended as being different from the real being:

... since God cannot be thought except as real, reality is one of His essential attributes, and, therefore, $\mathrm{He}$ is not a mere ideal postulate of the reason, but a subsistent reality.

9 The law is instituted by God for the rational enactment of the citizenly societas. The reason is the medium by which humankind interprets natural law. With reference to Aquinas' perception of virtue, humankind is in this manner brought closer to God and this then involves the perfection of the citizenly societas. Rosmini would have followed the same approach.

10 This is a derivation from Hegel's dialectic materialism. 


\section{ROSMINI'S NATURAL THEOLOGY}

According to Rosmini, theology deals with the Absolute Being, namely God. $\mathrm{He}$ is furthermore of the opinion that humankind does not have the ability to come to a full knowledge of the perfect Being (God). The perfect Being in his totality and completeness thus transcends human knowledge or existence. It means that humans cannot have a perception of how God look likes or what $\mathrm{He}$ is. Human reason can only know that which is revealed to it through nature. According to Rosmini, humankind is inclined to attribute something positive to God which shows a similarity to human intelligence. However, this similarity also accompanies differences such as that, although humankind is an effigy of God, it is unlike God, not universal and eternal, so that we are not able to adequately comprehend God. Therefore, we know that God exists rather than what the exact nature of God is. On the question as to how human intelligence is able to know God, Rosmini is of the opinion, as was Thomas Aquinas, that when we mention that God is intelligent, this does not mean that God is subject to the same norms we use for human intelligence. Rosmini is of the opinion that we must use the term "analogically". The Thomist, Copleston, cites Thomas Aquinas:

[We] cannot mean that God is intelligent in precisely the same way that a man is intelligent: we cannot, that is, by using the term in a univocal sense. Nor can we be using it purely equivocally. If we were, the term would have no meaning when applied to a being transcending our natural experience [...] we predicate of God something positive to which human intelligence bears some resemblance ... (Copleston 1952:93).

However, Rosmini states that we can know God, if we do not form a positive understanding about God, but indeed a negative one. ${ }^{11}$

Natural theology demonstrates the existence of the perfect Being (God). Rosmini identifies four proofs for the existence of God (Copleston 1952:90). ${ }^{12}$

11 Davidson (1882:334):

[T] his sort of cognition is called negative and is the only sort possible in natural theology, which treats of being in its absoluteness, of being, not as known to humankind, but as it is in itself.

12 Unlike Rosmini, Aquinas advanced five proofs for the existence of God. According to Aquinas, the autonomy of reason is valid on the natural terrain. He mentions that the highest product of humankind's natural reason is natural theology, a theology construed through reason exclusively with the assistance of the natural particulars (no revelation), as did Aristotle. Aquinas is of the opinion that there can never be contradiction between the terrains of reason (knowledge and faith), because Christian truth surpasses and never contradicts the intellect. The reason: Truth is one, and relies on God. Natural theology serves as a forerunner for Scriptural theology “... for faith presupposes natural knowledge, even as grace presupposes nature." In 
He thus establishes himself as an independent thinker by constructing his own natural theology, alongside Thomistic doctrine. Although there are certain tangents between his natural theology and that of Thomas Aquinas, these are not perfect. Rosmini once again confirms his recognition as adherent to classical Thomism in so far as two of his proofs for the existence of God correspond directly with Thomas Aquinas's natural theology. ${ }^{13}$ The fact that the remainder of Rosmini's proofs for the existence of God differ from those of Thomas Aquinas does not mean that Rosmini did not maintain a Catholic Christian view of God. Tangents are indeed found between the proofs for the existence of God advanced by Rosmini and those advanced by Thomas Aquinas.

The first proof states that the essence of Being is not merely nothing, but is rather something eternal and necessary. According to Rosmini, the essence of perfect Being, which is eternal and necessary, must also be real and moral. $\mathrm{He}$ is of the opinion that the essence of Being is infinite and exists under all three forms. The essence of Being is composed of the following three forms: the ideational, the real and the moral. ${ }^{14}$ It is God.

Rosmini derives the second proof for the existence of God from the ideational form of the perfect Being. In his opinion the ideational form is the light which creates intelligence. Intelligence or (the light of) reason is equated with God. The subject as eternal light must have complete knowledge and this knowledge must not be transient. God is perfect knowledge, God is eternal light and God is everlasting. According to Rosmini, this subject, who exists simultaneously as infinite object, is an embodiment of goodness and moral

his natural theology Aquinas provides five proofs for the existence of God, namely the fact of movement, origin, necessity, degrees of perfection and purposefulness.

13 Strauss (et al. 1978:18-9). According to Strauss, there are parallels between Thomas Aquinas' first proof for the existence of God and Rosmini's third proof for the existence of God. Thomas Aquinas's first proof for the existence of God determines that nothing can move without it being moved and this moving agent is moved in turn. An infinite series is impossible and for this reason a First Immobile Mover exists - and Aquinas calls this "God." Aquinas's first proof for the existence of God is in accordance with that of Rosmini who bases his First Cause of everything upon the fact that reason moves from the contingent to the necessary. Both recognise a First Cause of everything, namely God.

The fourth Thomistic proof for the existence of God is in accordance with Rosmini's fourth proof for the existence of God. Aquinas's fourth proof for the existence of God is as follows: There are degrees of goodness, truth, etc. There is a best, a most true, etc. and consequently also something which exists in the superlative degree. Thus, there must be something which is the cause of all things' existence, goodness, etc. Aquinas calls this God.

14 Davidson (1882:326). The essence of Being is God. 
perfection. Thus, perfect ideational Being (in the light of intellect and reason) is absolute. It is God. ${ }^{15}$

Rosmini derives the third proof from the real form, according to which the reason or thought proceeds from the contingent to the actual - until the First Cause of everything, God. ${ }^{16}$ No thing can be the cause of its own motion or change. The cosmos thus must have a cause or an origin which stands outside itself. Like Aristotle and Thomas Aquinas, Rosmini views the universe as eternally existent, and its cause is viewed as also being eternal. Moreover, its origin has to be perfect, because it is the criterion against which everything in the material world has to be tested. It is also the first cause of everything which moves and changes upon earth. However, it cannot move itself. God is thus the cause of all movement, but cannot move Himself. God is the pure Form, the end goal of perfection to which everything must strive.

The fourth proof is derived from the moral form. Rosmini is of the opinion that the moral form encompasses the qualities of universality, eternity and necessity. These qualities are attributed to the absoluteness of God. God would have been nothing, if $\mathrm{He}$ did not have an absolute existence. There is thus an Absolute Being, namely God (Davidson 1882:336).

In the case of Thomas Aquinas, natural theology proves that we can know God by means of our reason. Rosmini, however, assumes that we can know God by means of the "light of reason" (Godly revelation). We cannot know more about God than is allowed for by the necessity of the essence of Being. Rosmini cites Davidson in saying that this forms the limitation of our knowledge about God on the natural terrain as against the supernatural terrain (Rosmini 1991b:2354; Davidson 1882:342-7). ${ }^{17} \mathrm{He}$ once again clarifies that our knowledge of God is negative knowledge (Davidson 1882:340). Rosmini explains that the negative knowledge humankind has about God is found in, for example, the fact that it is

15 Davidson (1882:335-6). Rosmini views God as Infinite Object. He asserts:

... a subject which, at the same time, exists as an infinite object is the most perfect possible union of the two, and hence it is the infinite act of goodness or moral perfection that constitutes the third primordial form of being.

16 Venter (1970:14). Rosmini's third proof for the existence of God shows parallels with the Aristotelian-Thomistic proof for the existence of God.

17 Davidson (1882:342-7). Rosmini asserts that that being which is naturally observed by humankind, is not God, because things are named in accordance with how they are understood or seen. Those ideas which are characteristic of Godly essence and which convince us of the necessity of God's existence are not God Himself; they merely contain proof of his existence. The concept "God" is thus merely a sign, an indication of Him. Just so is the nature of the negative observation. Rosmini is of the opinion that the name "God," is merely the intellectual name of which we speak. It is not God. It is indeed the subject of the opinion that God exists. 
illogical to declare that God has, for instance, human rights. We cannot arrive at a perception of God without surpassing human intelligence or reason:

[But] this absolute being, which we neither intuite nor perceive, we can know no more than is shown us by the necessity of the essence of being, the object of the idea. This is the limit of the knowledge which we can have of God in the natural order, and hence our knowledge of the divine nature may be called a negative-ideal knowledge (Davidson 1882:337).

Human rights can only be applied to human beings and not to God. God does indeed serve as an ontological source, where, for example, human rights as found in human society have their origin:

... (person) ... mean a substantial relationship, that is, a relationship found in the intrinsic order of being of a substance. When these constitutive, ontological elements of person are found in the human subject, we have arrived at the concept of human person ... "person" as the fount of moral, human action, is the foundation of all right in human relationships because its very own worth is drawn from that which ultimately forms the human intellective subject. This moral excellence and superiority by right, which elevates the human person above the whole of nature, must have the same source as all morality and right... we find ourselves in need of a suitable basis for the development of our understanding of the nature of human rights ... (Rosmini 1991a:vii-xii; Cleary 1992:29). ${ }^{18}$

Rosmini asserts that the essence of his natural theology displays similarities with certain qualities of traditional natural law. The qualities of eternity, universality and necessity, etc., which are indicative of God, are precisely those qualities contained in the natural law: "[This] authority is equally absolute,

Rosmini confirms that, by nature, we cannot see God. He goes even further than Thomas Aquinas and Augustine, who respectively said: ".. intellectus separatus, secundum fidei documenta, est ipse Deus, qui est creator animae, et in quo solo beatificatur... Unde ab ipso anima humana lumen intellectuale participat...", and "... solus Deus dat intellectum; Deus enim per ipsum, quod lux est, illuminat pias mentes." (Davidson 1882:338; " $\ldots$ the intellect is formed distinctly, whereafter faith serves as proof, which is granted to us by God, the creator of the soul. God also gifted the human soul with an intellect" and "God alone is the giver of the intellect. God exists of His own accord. God is light. He illuminates the thoughts so that it achieves piousness.")

Rosmini explains further that the first being is not God, because it lacks something which belongs to the Godly being. The being lacks completeness, and thus does not possess independent existence. If the object of conception lacks anything, the thing that is being observed will not be God. Anything that is imperfect is not God. If a thing or a being is completely understood or seen, it will not have a beginning or an inception, and will be worthy of the name God.

18 According to Cleary (1992:29), Rosmini states that human rights can be ontologically carried through to God: 
unchangeable, impassible and eternal because these are all properties essential to the law of justice and uprightness" (Rosmini 1991a:384). The godly and exalted qualities are, according to Rosmini, those which afford the natural law its elevated status. Rosmini thus construes natural law as a God-given right, from which the principles of law and justice can be derived by means of human reason (Rosmini 1991a:384). Because human reason is a foreshadowing of the Godly ratio (reason), humankind is capable of knowing, with the assistance of its reason, that part of the natural law which is applicable to it. ${ }^{19}$

On this basis, Rosmini (1991b:238) mentions that the existence of God can be explained with the assistance of human reason. In addition, Rosmini (1991b:238-9) is of the opinion that the reality of an Absolute Being may not be doubted, not even by the critical philosophy of Kant, Hegel, Fichte and Schelling:

[The] Critical philosophy — the German school dependent upon Kant - saw that universality could not be explained by dependence upon sense. But these philosophers, in establishing forms or categories of the mind as source of the universal content of idea, admitted more than was necessary on the one hand, and on the other prepared the ground for total scepticism. Some innate element was necessary to the mind, but not categories or subjective forms (Cleary 1992:17).

Rosmini believes that, with reference to a priori knolwedge, we can only have a negative truth or understanding of God (Rosmini 1991b:243). According to Rosmini, the positive understanding of God contains actual qualities that contradict an understanding of God. He explains: "[It] would be absurd to attribute

The innate dignity conferred on human beings by their very existence as intelligent beings becomes an absolute, inviolable right to be recognized wherever I find it. What is said about human beings is a fortiori true of the Absolute which confers upon them the light of being. All moral good is found in the acknowledgement of the classes of intelligent beings at their level of relationship with Absolute Being; no moral good can be found outside the ranks of intelligent beings.

With respect to the ontological basis of human rights in the human societas, Rosmini (1991a:480) explains:

[T]hrough this relationship the person becomes moral and enters the sphere of things which partake of the infinite and acquire an infinite value ... Through this act the human being merits, and spontaneously moves to unite himself to all beings and to the source of beings, loving them all and receiving love from them all. He gives himself to all beings, and they give of themselves to him. He thus widens his own limits, bringing his restricted, deficient nature to completion ... Such is the end of human beings, the noblest end of person, and hence, the end of human nature ...

19 Rosmini (1991a:384) explains: "Those, however, are more fully endowed whose gaze, formed more purely and sharply by nature, absorbs at first sight greater light from the divine ray of justice." 
these characteristics to the divine essence ..." (Rosmini 1991b:243). According to Rosmini, God is the criterion for reality or truth. Concerning "things," God is the reality. ${ }^{20} \mathrm{He}$ mentions that if we think something independent of ourselves, we regard this something as a means of existence that is different to our own (subjective) existence (Rosmini 1991b:33). He also explains that when we think, we, as subject, will not become the object of our own thoughts. In his opinion thoughts (intellect or reason) end in object (in this context God). This is different from the thinking subject (Rosmini 1991b:34). If subject assumes humankind, than object assumes God (Rosmini 1991a:418). The object of our thoughts is human reason, which is equal to God with reference to the principle of analogia entis and imago Dei: "[Just] as he said image [...] he also said likeness in order that we may render ourselves like God according to human forces." (Rosmini 1991a:447). But we are not God, and we will not become God.

Consequently, God is the source of the intellectual soul component (Rosmini 1991a:442). The soul is indicative of godly qualities. An analogy is further assumed between God and the human soul. In my opinion this view of Rosmini on humankind displays similarities with Thomism, in which the soul is also viewed as being godly.

\section{CONCLUSION}

The aim of this article was to develop how human reason is viewed by Rosmini as a sign of the image of God. According to him, humankind must allow its reason to guide its actions in such a way that it is able to imitate the exaltedness of the godly qualities of universality, eternity and necessity. He believes that human beings can only know that which is revealed to them through reason or intellect. The essence of Rosmini's natural theology displays similarities with certain qualities of traditional natural law. These qualities of eternity, necessity, etc., which are indicative of God, are precisely those contained in natural law and which afford natural law its sublime status. Rosmini construes natural law as offset of human reason. Because human reason is a foreshadowing of the godly reason (ratio), humankind is capable of knowing with the assistance of its reason that part of the natural law which is applicable to it. On this basis the existence of God can be explained with the help of human reason. With the assistance of human reason, it can be determined that God is the source of human reason (due to the intellectual/godly soul component). Thus an analogy between God and the human soul (reason/intellect) is therefore firmly set. This view of Rosmini about humankind displays similarities with Thomism, in which the soul is also viewed as being godly.

20 The term "thing" can readily be replaced with "being". 


\section{BIBLIOGRAPHY}

Cleary, D.

1992. Antonio Rosmini. Introduction to his life and teaching. Durham: Rosmini House.

Copleston, F.

1952. Medieval philosophy. London: Methuen and Co.

DAVIDSON, T.

1882. The philosophical system of Antonio Rosmini-Serbati. Translated with a sketch of the author's life, bibliography, introduction, and notes. London: Kegan Paul, Trench \& Co.

John-Stevas, N.St.

1955. Philosophy of law. By Giorgio Del Vecchio. Translated from the $8^{\text {th }}$ edition by Thomas Owen Martin. Washington: The Catholic University of America Press. The Modern Law Review 18 (1):82-84.

Rosmini, A.

1991a. Anthropology as an aid to moral science. Durham: Rosmini House.

1991b. Certainty. Durham: Rosmini House.

1999. Psychology. Development of the human soul. Glasgow: Bell \& Bain Limited.

Strauss ET AL.

1978. Kompendium vir studente in die Wysbegeerte. Durban: Butterworth.

VAN DER VYVER, J.D.

1975. Hedendaagse Calvinistiese en Rooms-Katolieke natuurregsteorieë. Tydskrif vir Hedendaagse Romeins-Hollandse Reg 38(1):66.

VENTER, E.A.

1970. Wysgerige temas. Tweede druk. Bloemfontein: Sacum Beperk.

Winterton, F.

1888. Review. Papal condemnation of Rosmini. Notes. Mind 13(52):622-626.

Keywords

Rosmini

God

Soul

Natural theology

Existence

Ontology
Trefwoorde

Rosmini

God

Siel

Natuurlike teologie

Bestaan

Ontologie 